(C) 1988 ISIJ

/IIIIIIIIIIIIIIIIIIIII!

技術報告

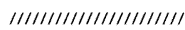

\section{取鍋加熱精錬法の開発}

\title{
Development of Ladle Arc Refining Process
}

Hideaki Fujimoto, Toshiyuki Soejima, Hiroshi Matsumoto, Hideo Matsui, Shinichi MaEDA, Tsuyoshi Mimura and Kanehiro OGAWA

\begin{abstract}
Synopsis :
In order to meet the recent demands for higher quality steels and rationalization in manufacturing processes, the ladle refining technology has advanced remarkably.

Kakogawa works installed the ladle refining furnace (LF) in January 1986 for the stable production of high-grade steel and to decrease the thermal burden in the LD converter. This equipment is capable of arc heating, strong top agitation, and slag skimming. Furthermore, combining this equipment with the existing hot metal pretreatment and RH degassing equipment has made possible the production of low phosphorous and sulfur content steel.

Also, the production technology of clean steels such as steel tire-cord has been established by making the shape control of non-metallic inclusions through the ladle slag refining.

Key words : ladle refining furnace; arc heating; top bubbling; slag skimming; ultra low sulfur content steel; steel tire-cord.
\end{abstract}

\section{1. 緒}

言

近年, 鋼材品質要求の厳格化, あるいは鋼材使用条件 の苛酷化にこたえるため, 取鍋精錬法は高級鋼の安定量 産プロセスとして飛躍的な発展を遂げている.

特に, 酎サワーガス用ラインパイプ鋼板, 低温圧力容 器用鋼板などでは, 鋼材特性の改善をはかるため, 鋼中 のりん (P), 硫黄 $(\mathrm{S})$, 酸素 $(\mathrm{O})$ などの不純物元素 を徹底的に低減させることが必須条件となつている。 た，タイヤコード用鋼のように介在物に対する要求が厳 しい材料では，スラグ精錬による安定した介在物形態制 御技術が求められている.

このような清浄鋼の安定製造を可能にするとともに, 転炉の熱負荷を軽減し，合理的な転炉-取鍋精錬プロセ スを確立するため，神戸製鋼所では溶鋼加熱及びスラグ 精鍊機能を有した $240 \mathrm{t}$ アーク加熱式取鍋精錬設備 (Ladle Arc Refining Furnace ; 以下 LF と略す) を設置 し, 1986 年 1 月から操業を開始した.

本報では, 本 $\mathrm{LF}$ 設備の設備概要, 操業特性及び極 低硫鋼，タイヤコード用鋼を代表とする清浄鋼の製造技
術について報告する。

\section{2. 取鍋加熱精錬設備の概要}

\section{$2 \cdot 1$ 設備概要}

Fig. 1 に本 LF 設備の概要図を示す。本設備の持つ 機能・特徴は以下のと㧍りである.

1) 加熱時間を短縮し，連連鋳へ対応できるようにす るため, $42000 \mathrm{kVA}$ の大型トランスを使用している.

2 ）スラグ精鍊を効果的に行うため，強攪拌が可能な 上吹きガス㩭找法を採用している.

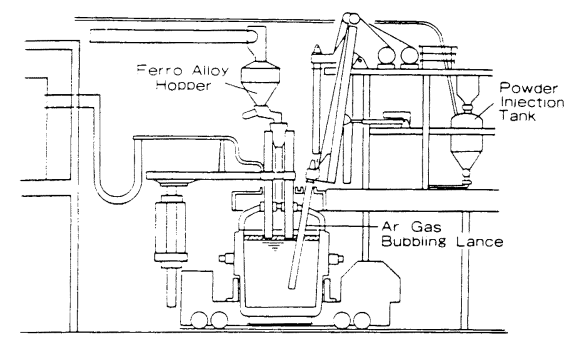

Fig. 1. Schematic diagram of ladle arc refining.

昭和 61 年 10 月本会講演大会にて発表 昭和 62 年 10 月 1 日受付 (Received Oct. 1, 1987)

* (株)神戸製鋼所 加古川製鉄所 (Kakogawa Works, Kobe Steel, Ltd., 1 Kanazawa-cho Kakogawa 675-01)

*2 (株)神戸製鋼所 材料研究所 (Materials Research Laboratories, Kobe Steel, Ltd.) 


\begin{tabular}{|c|c|c|c|c|}
\hline $\begin{array}{l}\text { Treatment } \\
\text { Process }\end{array}$ & \begin{tabular}{|l|} 
BOF \\
Tapping \\
\end{tabular} & $\begin{array}{l}\text { Slag } \\
\text { Draggar! }\end{array}$ & Arc Refining & $\mathrm{RH}$ \\
\hline Flux & & $\begin{array}{c}\text { Addition } \\
r \mid\end{array}$ & Addition & \\
\hline Alloy & & & $\begin{array}{c}\text { Addition } \\
\zeta\}\end{array}$ & \\
\hline Electric Power & & & $\stackrel{12 \sim 20 \mathrm{MW}}{\longleftarrow}$ & \\
\hline Ar bubbling & & & $0.5 \sim 1.0 \mathrm{Nm}^{3} / \mathrm{min}$ & \\
\hline 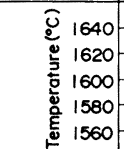 & 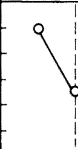 & & & \\
\hline
\end{tabular}

Fig. 2. Operation process of arc refining.

3 ）極低硫鋼の溶製及び介在物の形態制御のため, 粉 体吹达み装㯰を併設している。

4 ) 集塵効果の向上と炉蓋内への空気巻込みによる吸 窒を防止するため, 水冷炉蓋の直上に間接集塵型の集塵 フードを設置している.

5 ) 転炉スラグを効率的に除去するとともに，除涬に よる裸湯面からの放熱を防止するため, 上吹きガス攪 找・造涬剂添加併用スラグドラッガーを採用している.

\section{$2 \cdot 2$ 操業パターン}

本設備における一般加熱材の操業パターン例を Fig. 2 に示す。転炉では従来より約 $60^{\circ} \mathrm{C}$ 低温で出鋼し，ス ラグドラッガーで転炉の酸化性スラグを除去した後, 約 $10 \mathrm{~kg} / \mathrm{t}$ の造涬剂を添加する。造滓剂は溶製目的別に適 正なスラグ組成となるように調整する.

その後, 加熱精鍊位置へ移動し，加熱・攪拌を行う. 加熱初期に合金鉄を投入後，造滓剂を追加投入し，サブ マージドアーク加熱に必要なスラグ厚みとする。造滓剤 の滓化後, 電力負荷を上げるとともに, 加熱効率の高い 電力パターンを採用して, 処理時間の短縮をはかつてい る。

\section{3. 取鍋加熱精錬処理の諸特性}

\section{$3 \cdot 1$ 取鍋内撜拌特性}

本設備の取鍋内混合特性及びスラグーメタル間物質移 動特性について，水モデル及び実機テストにより調査す るとともに，誘導攪抖を行つている ASEA-SKF 法 ${ }^{1)}$ との比較を行つた。

( 1 ) 混合特性

実機の $1 / 13$ スケールの水モデル装置に, トレーサー として $\mathrm{KCl}$ 水溶液を添加し, その濃度変化を 2 個の電 気伝導度計により測定した. 均一混合時間 $\tau$ は, 測定し た2 点間の濃度差がトレーサー添加による全濃度変化の $\pm 1 \%$ 以内になるまでの時間とした。

実機テストにおいては，トレーサーとして Cuを 0.2

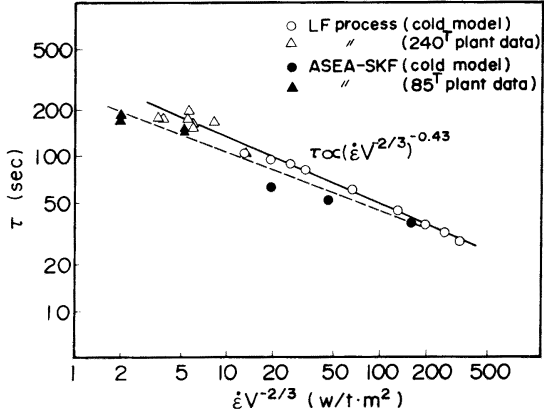

Fig. 3. Comparison of mixing time between LF process and ASEA-SKF process.

$\mathrm{kg} / \mathrm{t}$ の量を添加した後，連続サンプリングを行い，濃 度変化がなくなるまでの時間としててを求めた.

得られた結果を均一混合時間 $\tau$ と攪挥動力值 $\dot{\varepsilon}$ の関係

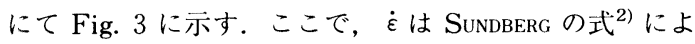
り算出し, 森ら ${ }^{3)}$ の解析に従つてスケール因子 $V^{-2 / 3}$ との積とした．森らの結果と同様に， $\tau \propto\left(\dot{\varepsilon} V^{-2 / 3}\right)^{-n}$ の関係が認められ，本プロセスについては $n=0.43$ の 値が得られた。また，誘導攪找を行う ASEA-SKF 法 と比較すると, 浴内混合は ASEA-SKF 法の方が優れ ているという結果が得られた。

攪拌方式による差が, 流動状態と物質移動過程のどち らに起因しているかを調査するために，浴内循環流の循 環時間 $\theta_{C}$ を測定した。この $\theta_{C}$ は, 電気伝導度セルあ るいは溶鋼連続サンプリングにより測定されたトレー サーの濃度変化において, 現れる濃度ピークの時間間隔 として求めた. 物質移動過程が対流支配及び乱流拡散支 配であると仮定し，さらに乱流拡散支配の場合の混合距 離 $l \propto L$ であると仮定すると, 浅井ら ${ }^{4)}$ の解析結果より, 均一混合時間 $\tau$ と循環時間 $\theta_{C}$ の関係は次式で与えられ る。

$\tau \propto L / v \propto \theta_{C}$

ここで, $L:$ 代表長さ, $v:$ 流速である.

Fig. 4 に, 水モデル及び実機テストで得られた循環 時間 $\theta_{C}$ と $て$ 関係を示す. 本プロセス及び ASEA-SKF 法とも, ( 1 )式の関係が成り立つており, $\tau \doteqdot 5 \theta_{C}$ の同一の関係が得られた。従つて，本プロセス 及び ASEA-SKF 法において，物質移動過程に差はな いと考えられる.

以上のことから，本プロセスのようなガス攪拌におい て, 同じ擤找動力のもとで均一混合時間が長いのは, 攪 找動力が浴全体の流動に有効に作用せず，循環時間が長 くなることによるためと推定される。これに関連して, 


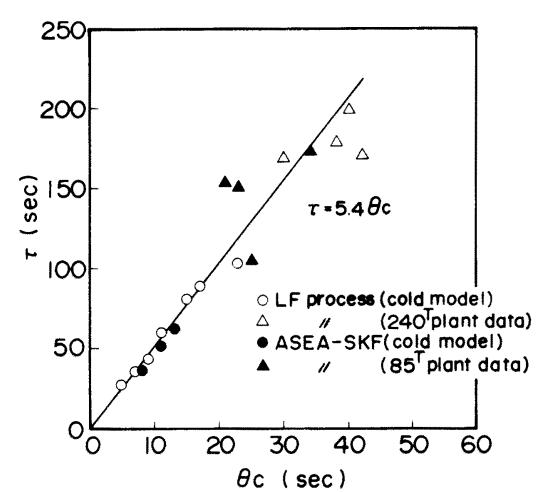

Fig. 4. Relation between $\tau$ and $\theta_{C}$.

小川ら ${ }^{1)}$ はガス攪拌及び誘導攪拌の水モデルにおいて流 速分布を測定しており，ガス攪拌では気泡周辺及び液表 面で流速が特に大きく，系全体では不均一な流れである のに対して，誘導攪找では系全体が比較的均一な流動状 況を示していることを明らかにしている。本プロセス及 び ASEA-SKF 法における均一混合時間及び循環時間 の差は,このような流動状態の違いに起因していると推 定される。

\section{( 2 ) スラグーメタル間物質移動特性}

水モデル実験は前述と同一の装置を用いて, 安息香酸 を含浸させた発泡スチロール粉末を液面に添加し，水中 に拡散した安息香酸濃度を電気伝導度計により測定し て，(2)式により物質移動係数 $k m$ を求めた。

$$
\ln \left(1-\frac{C}{C_{i}}\right)=-k m \frac{A}{V} t
$$

ここで, $C$ : 時刻 $t$ の濃度, $C_{i}$ : 液側界面における安 息香酸濃度, $A$ : 界面積, $V$ : 液体積である.

実機テストにおいては，上置きスラグを用いた脱硫処 理における鋼中 [S]の変化を(2)式により整理して $\mathrm{km}$ を求めた。

小川ら は) は浸透モデルをもとに，攪拌動力值 $\dot{\varepsilon}$ と物質 移動係数 $\mathrm{km}$ の関係として $(3)$ 式を導いている.

$$
k m / \sqrt{D} \propto\left(\dot{\varepsilon} V^{-2 / 3}\right)^{n}
$$

ここで, $D:$ 溶質の拡散係数である.

この式をもとに, Fig. $5 に k m / \sqrt{D}$ と $\dot{\varepsilon} V^{-2 / 3}$ の関 係を示す，ASEA-SKF 法と比較して，本プロセスの物 質移動係数は約 10 倍であり，上吹き強攪找を用いた本 プロセスは溶鋼の脱硫スラグ精錬に有利である。また， コールドモデルテストでは従来の LF 法で採用されて いるポーラスプラグによる底吹きガス攪拌と比べても， 上吹きガス攪拌は $\mathrm{km}$ が大きく，ノズル孔径を大きくし て気泡径を大きくすることにより，さらに $\mathrm{km}$ は大きく

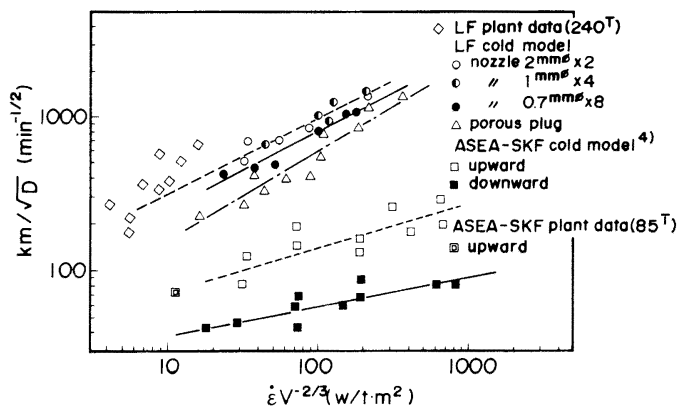

Fig. 5. Relation between $k m / \sqrt{D}$ and $\dot{\varepsilon} V^{-2 / 3}$.

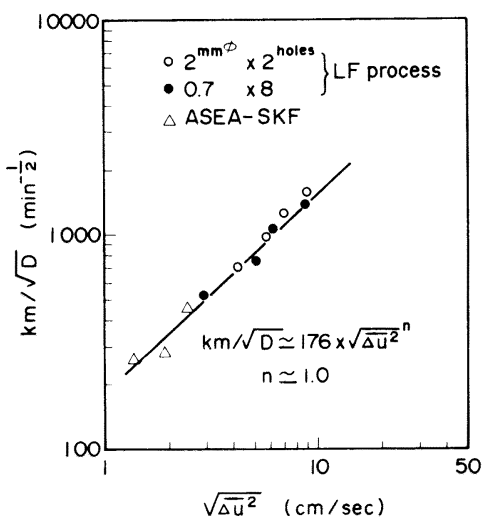

Fig. 6. Relation between $k m / \sqrt{D}$ and turbulent fluctuational velocity $\sqrt{\overline{\Delta u}}$.

なつた。

ガス攪拌と ASEA-SKF 法の誘導擤找における物質 移動係数に関し, 小川ら² はその差がスラグーメタル界 面での乱流変動速度（流速の時間変化の標準偏差）によ り，良く整理できることを示している。この結果にもと づき，Fig. 5 で見られたガス攪找に扔けるノズル孔径 の違いによる物質移動係数の差を, 界面の乱流変動速度 で整理したものを Fig. 6 に示す. あわせて, ASEA-SKF 法の結果を示した. 小川らの結果と同様に, 物質移動係数は界面での乱流変動速度に支配されてお り，ノズル孔径が大きい場合には気泡径の増大にともな い, スラグーメタル界面の乱れが増加し, 物質移動が促 進されたものと推定される．Fig. 5 の実機ガス攪找の 結果において，大きな $k m$ が得られているのは，主に水 モデルと同様に大きな乱流変動速度が得られていること によると考えられるが，この他実機においてはスラグの 巻込み等による界面積の増加があわせて起こつていると 考えられ，これにより水モデル結果とくらべて， $k m$ が 


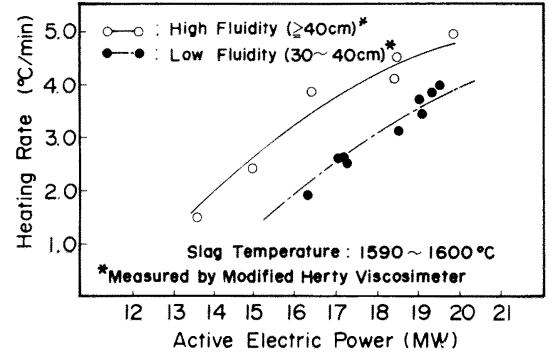

Fig. 7. Relation between heating rate and active electric power.

さらに大きくなつたと推定される。

以上から，上吹きガス攪找を採用した本プロセスは ASEA-SKF 法と比較して, 均一混合特性は若干劣るも のの, スラグーメタル閒物質移動特性に優れており, 上 置き脱硫などのスラグ精錬を行うのに有利なプロセスと 考えられる.

\section{$3 \cdot 2$ 加熱特性}

LF での加熱方法として，加熱効率の向上及び取鍋や 上吹きランス酎火物の保護のため, サブマージドアーク 加熱を行つている.

加熱速度を大きくするためには, 電力負荷を増大させ ることのほかに，サブマージドアーク加熱に適したスラ グを造涬する必要がある。流動性の異なるスラグを用い た場合の加熱速度の比較を Fig. 7 に示す. なお，スラ グの流動性は Modified Herty Viscosimeter ${ }^{6)}$ を用いて 測定した流動長さで評価した。

低融点で流動性の高いスラグを用いることにより， $4^{\circ} \mathrm{C} / \mathrm{min}$ 以上の加熱速度を得ることが可能である。これ はサブマージドアーク加熱において，スラグ流動性の向 上により，スラグへの電極の浸漬が十分となり，オープ ンアークの発生による輻射放熱が抑えられることのほか に，アークによるスラグ抵抗熱が溶鋼に伝達しやすくな るためと考えられる.

アーク加熱により取鍋耐火物の溶損が増加するため,

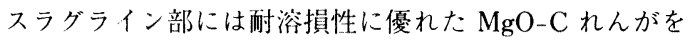
使用しているが, 取鍋酎火物の溶損量を低減するには, 以下の対策を適切に取る必要がある.

1) サブマージドアーク操業を行い, ホットスポット による局部溶損を防止する.

2 ）スラグの過熱を抑制する.

3) $\mathrm{MgO}$ の溶出を抑えるようにスラグ組成をコント ロールする.

ここで，1）ホットスポットの防止，2）スラグ過熱 の抑制のためには, 電力負荷及びガス穓拌の適正化とと

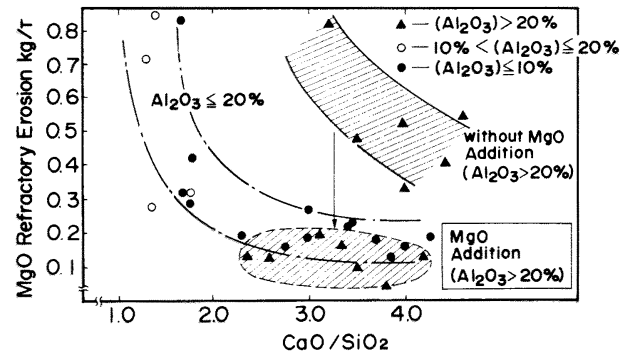

Fig. 8. Relation between $\mathrm{MgO}$ refractory erosion and slag basicity.

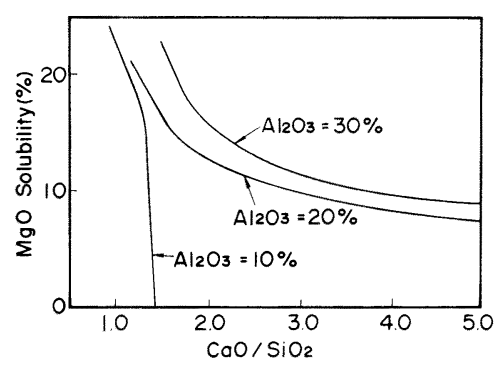

Fig. 9. Relation between $\mathrm{MgO}$ solubility and slag basicity in $\mathrm{CaO}-\mathrm{MgO}-\mathrm{SiO}_{2}-\mathrm{Al}_{2} \mathrm{O}_{3}$ system ${ }^{5)}$ at $1600^{\circ} \mathrm{C}$.

もに, 前述のスラグの低融点化, 低粘性化が必要である. しかし，スラグが低融点・低粘性になるに従つて，逆に 取鍋耐火物の溶出は増大する傾向が認められた.

通常用いられる $\mathrm{CaO}-\mathrm{MgO}-\mathrm{SiO}_{2}-\mathrm{Al}_{2} \mathrm{O}_{3}$ 系スラグにお いて, スラグ中 $\mathrm{Al}_{2} \mathrm{O}_{3}$ 濃度が高いほど, あるいは塩基 度が低いほど，低融点でしかも $\mathrm{MgO}$ 溶解度の高いスラ グとなるため, 取鍋耐火物の溶損量は増加する。その関 係を Fig. 8 に示す.これは, Fig. 9 に示すこの系の $\mathrm{MgO}$ 溶解度の傾向とよく一致している。 そこで, 取鍋 酎火物の溶損を抑え，しかも低融点組成となるように， 軽焼ドロマイトを添加してスラグ中の $\mathrm{MgO}$ 濃度が 610\%になるように調整したところ，Fig. 8 に示すよう に塩基度, $\mathrm{Al}_{2} \mathrm{O}_{3}$ 濃度にかかわらず, 溶損量は低位安定 した.

この結果, 加熱効率の高い高電力負荷操業が可能とな るとともに, 取鍋スラグライン部の溶損速度は大幅に低 下し，取鍋耐火物寿命が向上した.

\section{4. 清浄鋼の製造}

\section{$4 \cdot 1$ 極低硫鐝}

取鍋加熱精錬処理では，スラグの酸素ポテンシャルを 低く抑えるとともに，スラグ組成の制御と溶鋼の強攪汼 


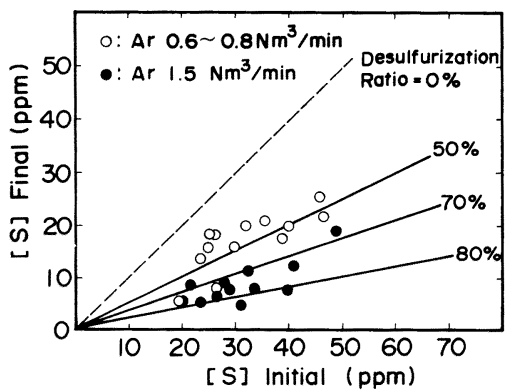

Fig. 10. Desulfurization during ladle arc refining treatment.

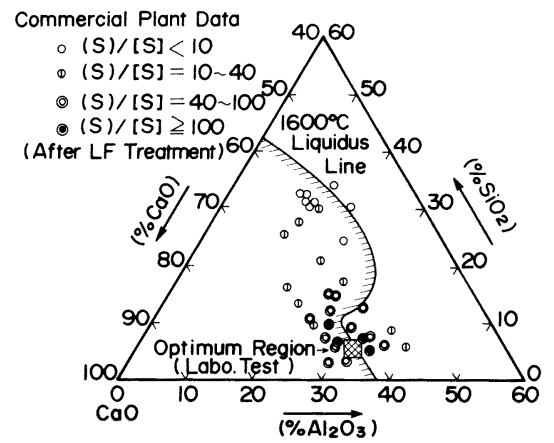

Fig. 11. Sulfur distribution ratio $(\mathrm{S}) /[\mathrm{S}]$ in $\mathrm{CaO}-\mathrm{SiO}_{2}-\mathrm{Al}_{2} \mathrm{O}_{3}$ slag.

により脱硫スラグ精鍊が可能である．Fig. 10 に，アー ク加熱時の脱硫効果を示すが, 加熱中の $\mathrm{Ar}$ ガス攪拌(流 量 : 0.6 0.8 $\left.\mathrm{Nm}^{3} / \mathrm{min}\right)$ により，30〜60\% の脱硫率が 得られる。また，アーク加熱後， $1.5 \mathrm{Nm}^{3} / \min に て 10$ $\min$ の強粯找により，さらに脱硫が促進され，70\%以 上の高脱硫率が得られた，使用したスラグ組成は，Fig. 11 に示するつぼょよび実機の実験結果において, $\mathrm{CaO}-\mathrm{SiO}_{2}-\mathrm{Al}_{2} \mathrm{O}_{3}$ 系の中で高分配比が得られたスラグ 組成 ( $\mathrm{CaO}: 60 \sim 65 \%, \mathrm{SiO}_{2}: 4 \sim 6 \%, \mathrm{Al}_{2} \mathrm{O}_{3}: 30 \sim 35 \%$ ) である。この組成は小倉らの報告值 ${ }^{7)}$ とほぼ一致してい る.

$\mathrm{S}$ 分配比 $L_{\mathrm{S}}(=(\% \mathrm{~S}) /[\% \mathrm{~S}])$ とスラグ組成の関係に ついては, DUFFY ら ${ }^{8)}$ の提案による光学的塩基度 $(\Lambda)$ を用いて整理できることが報告されている ${ }^{910)}$. 実操業 の結果で得られた光学的塩基度 $(\Lambda)$ と $\mathrm{S}$ 分配比 $L_{\mathrm{S}}$ の 関係を Fig. 12 に示す. 本図において, 光学的塩基度が 大きくなるにつれて S 分配比が増加しており，このデー 夕の回帰式として $(3)$ 式が得られた.

$\log L_{\mathrm{s}}=16.71 \Lambda-10.612$

以上の結果より, 脱硫用スラグ組成としては

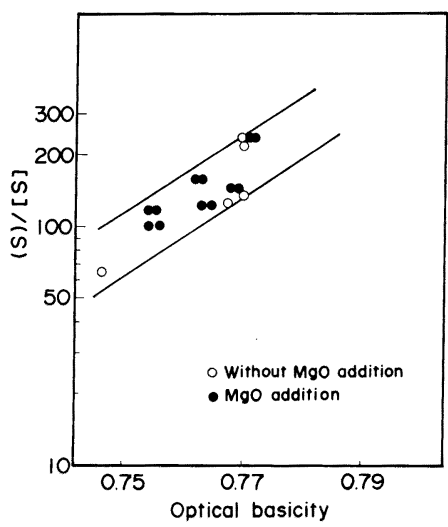

Fig. 12. Relation between (S)/[S] and optical basicity.

Table 1. Comparison of calculated sulfur distribution ratio $\left(L_{\mathrm{S}}\right)$ and optical basicity $(\Lambda)$ between with and without $\mathrm{MgO}$ addition

\begin{tabular}{c|c|cc}
\hline \multicolumn{2}{l|}{} & \begin{tabular}{c} 
Slag $\mathrm{A}$ \\
\multicolumn{2}{l|}{$\begin{array}{c}\text { Without } \mathrm{MgO} \\
\text { addition }\end{array}$}
\end{tabular} & $\begin{array}{c}\text { Slag B } \\
\text { (MgO addition) }\end{array}$ \\
\hline \multirow{3}{*}{$\begin{array}{c}\text { Slag Composition } \\
(\%)\end{array}$} & $\mathrm{CaO}$ & 62 & 56 \\
& $\mathrm{MgO}^{2}$ & 0 & 8 \\
& $\mathrm{SiO}_{2}$ & 8 & 6 \\
$\mathrm{Al}_{2} \mathrm{O}_{3}$ & 30 & 30 \\
\hline \multicolumn{2}{l}{ Sulfur distribution ratio $: L_{\mathrm{S}}$} & 245 & 235 \\
\hline \multicolumn{2}{l}{ Optical basicity $: \Lambda$} & 0.778 & 0.777 \\
\hline
\end{tabular}

$\mathrm{CaO}-\mathrm{SiO}_{2}-\mathrm{Al}_{2} \mathrm{O}_{3}$ 系の高塩基度低融点のスラグが望ま しい.しかしながら，このスラグを用いた処理において， 取鍋スラグライン部の $\mathrm{MgO}-\mathrm{C}$ れんがの溶損が大きく, $3 \cdot 2$ に示した軽焼ドロマイトの添加による酎火物の保護 が必要となつた。 そこで, 以下に脱硫能が高く, しかも 酎火物の溶損が少ないスラグ組成について検討した.

$\mathrm{CaO}-\mathrm{SiO}_{2}-\mathrm{Al}_{2} \mathrm{O}_{3}$ 系に少量の $\mathrm{MgO}$ を添加したスラグ における脱硫反応は, $\mathrm{CaO}$ による次の $(4)$ 式, あるい は $\mathrm{O}$ が $\underline{\mathrm{Al}}, \mathrm{Al}_{2} \mathrm{O}_{3}$ との平衡により決まつている場合に は( 5 )式で表される.

$$
\begin{aligned}
& (\mathrm{CaO})+\underline{\mathrm{S}}=(\mathrm{CaS})+\underline{0} \\
& 3(\mathrm{CaO})+2 \underline{\mathrm{Al}}+3 \underline{\mathrm{S}}=3(\mathrm{CaS})+\left(\mathrm{Al}_{2} \mathrm{O}_{3}\right)
\end{aligned}
$$

( 5 )式の平衡定数 $K$ を用いて $\mathrm{S}$ 分配比 $L_{\mathrm{S}}$ を表すと, 次の( 6$)$ 式が得られる.

$$
L_{\mathrm{S}}=\frac{(\% \mathrm{~S})}{[\% \mathrm{~S}]}=\frac{a_{\mathrm{Ca0}} \cdot a_{\mathrm{Al}}{ }^{2 / 3} \cdot f_{\mathrm{S}} \cdot M_{\mathrm{S}} \cdot 100 \cdot K}{\gamma_{\mathrm{CaS}} \cdot M_{\text {Slas }} \cdot a_{\mathrm{Al}_{2} 0_{3}}{ }^{1 / 3}}
$$

ここで, $M_{\mathrm{S}}: \mathrm{S}$ の原子量, $M_{\text {Slag }}$ : スラグの平均分子 量であり, $\mathrm{CaS}$ のル分率 $N_{\mathrm{CaS}}=(\% \mathrm{~S}) \cdot M_{\text {Slag }}$ 


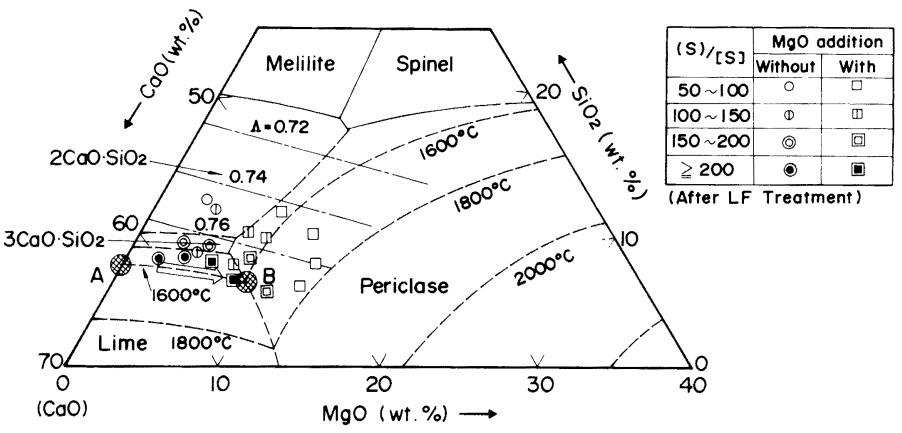

Fig. 13. Sulfur distribution ratio $(\mathrm{S}) /[\mathrm{S}]$ in $\mathrm{CaO}-$ $\mathrm{SiO}_{2}-\mathrm{MgO}$ system at $\mathrm{Al}_{2} \mathrm{O}_{3}$ $=30 \%$.

$/ 100 \cdot M_{\mathrm{S}}$ の関係を用いた.

(6) 式において, $a_{\mathrm{Al}}^{2 / 3} \cdot f_{\mathrm{S}} \cdot M_{\mathrm{S}} \cdot 100 \cdot K / M_{\text {Slag }}$ はほほ 一定であり, $\mathrm{S}$ 分配比 $L_{\mathrm{S}}$ は $a_{\mathrm{CaO}}, \gamma_{\mathrm{CaS}}, a_{\mathrm{Al}_{2} \mathrm{O}_{3}}$ の関数 となる.ここで, $\mathrm{MgO}$ 添加後の組成として, Fig. 13 中のBに示すような組成とすることにより, Lime 初晶 で Free limeを存在させて, $a_{\mathrm{CaO}} \fallingdotseq 1$ を保つことは可能 である。一方, $\gamma_{\mathrm{CaS}}, a_{\mathrm{Al}_{2} \mathrm{O}_{3}}$ に対する $\mathrm{MgO}$ の影響は不 明であるが, $a_{\mathrm{Al}_{2} \mathrm{O}_{3}}$ については $1 / 3$ 乗の指数により影 響は小さい。従つて, $\mathrm{MgO}$ を添加した場合にも, Fig. 13 の B の組成を選ぶことにより， $L_{\mathrm{S}}$ が大幅に低下す ることはないと考えられる.

また，前述のように $L_{\mathrm{S}}$ は光学的塩基度 $\Lambda$ の関数と して表されるが, $\mathrm{MgO}$ 添加を行わない場合および行つ た場合の典型的なスラグ組成を，それぞれ Fig. 13 の A : $\left(\mathrm{CaO}=62 \%, \mathrm{SiO}_{2}=8 \%, \mathrm{Al}_{2} \mathrm{O}_{3}=30 \%, \mathrm{MgO}=0 \%\right), \mathrm{B}$ $:\left(\mathrm{CaO}=56 \%, \mathrm{SiO}_{2}=6 \%, \mathrm{Al}_{2} \mathrm{O}_{3}=30 \%, \mathrm{MgO}=8 \%\right)$ と すると, それらの光学的塩基度は Table 1 のように, それぞれ $0.778,0.777$ とほとんど等しく, (3)式から $L_{\mathrm{S}}$ もそれぞれ 245,235 とほほ同じになると推定され る.

以上の検討結果をもとに，実操業においてスラグBの 組成を中心に，テストを行つた。その結果を Fig. 13 に あわせて示す。 $\mathrm{MgO}$ 添加により, $\mathrm{MgO}$ 濃度が増加した 場合に拝いても Lime 初晶の $1600^{\circ} \mathrm{C}$ 液相線近傍におい ては $L_{\mathrm{S}}$ の低下は認められなかつた。しかし，B点を越 えて Periclase 初晶域になると $L_{\mathrm{S}}$ は急激に低下する. これは， $a_{\mathrm{CaO}}$ が1以下に低下することのほかに，スラ グ融点が上昇することにより脱硫速度が減少するため, 到達 $L_{\mathrm{S}}$ が低下したと考えられる．また， $\mathrm{SiO}_{2}$ 濃度を 高めた場合，同じく $L_{\mathrm{S}}$ の急激な低下が認められるが, これは $a_{\mathrm{CaO}}$ の低下によると考えられる.

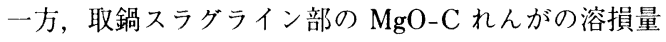
は, $3 \cdot 2$ で示したようにスラグ中の $\mathrm{MgO}$ 濃度を高める ことにより抑制することができる。このことから，

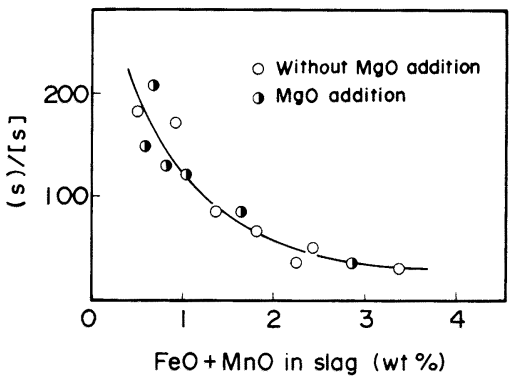

Fig. 14. Relation between $\mathrm{FeO}+\mathrm{MnO}$ is slag and sulfur distribution ratio (S)/[S].

$\mathrm{MgO}$ を添加したスラグ $\mathrm{B}$ の組成が高い脱硫能を得ると 同時に，酎火物溶損を抑制することができる最適な組成 であることが確認できた. Fig. 14 は $L_{\mathrm{S}}$ に対するスラ グ中 $(\mathrm{FeO}+\mathrm{MnO})$ の影響を示すが，これにおいても組 成 $\mathrm{B}$ を目標として $\mathrm{MgO}$ を添加した場合に，組成 $\mathrm{A} を$ 目 標として添加しなかつた場合と同様の高い $L_{\mathrm{S}}$ が得られ ている.

以上の結果から, $\mathrm{CaO}-\mathrm{MgO}-\mathrm{SiO}_{2}-\mathrm{Al}_{2} \mathrm{O}_{3}$ 系スラグに おいて， $\mathrm{MgO}$ を約 $8 \%$ 添加した高塩基度スラグを用い ることにより，取鍋酎火物の溶損を抑制しつつ， $\mathrm{S} \leqq 10$ $\mathrm{ppm}$ の極低硫鋼を溶製することが可能となつた.

\section{$4 \cdot 2$ タイヤコード用鋼}

ラジアルタイヤの補強材に使用されるスチールタイヤ コード用鋼は，0.15 0.38 mm $\phi$ の極細線領域までの伸 線加工や撚線加工に酎えうる品質が要求され，断線の原 因となる非延性な非金属介在物及び中心偏析の低減は重 要な課題である ${ }^{11)}$. 神戸製鋼において，タイヤコード 用鋼は従来 $\mathrm{RH}$ 脱ガス処理により溶製していた ${ }^{11)}$ が, 鋼材品質の安定・向上をはかるため, LF 法のスラグ精 錬機能を活用した製造技術を確立した。

夕イヤコード用鋼中の介在物は，スラグに起因する $\mathrm{CaO}-\mathrm{SiO}_{2}-\mathrm{Al}_{2} \mathrm{O}_{3}$ 系及び脱酸生成物を主成分とする 


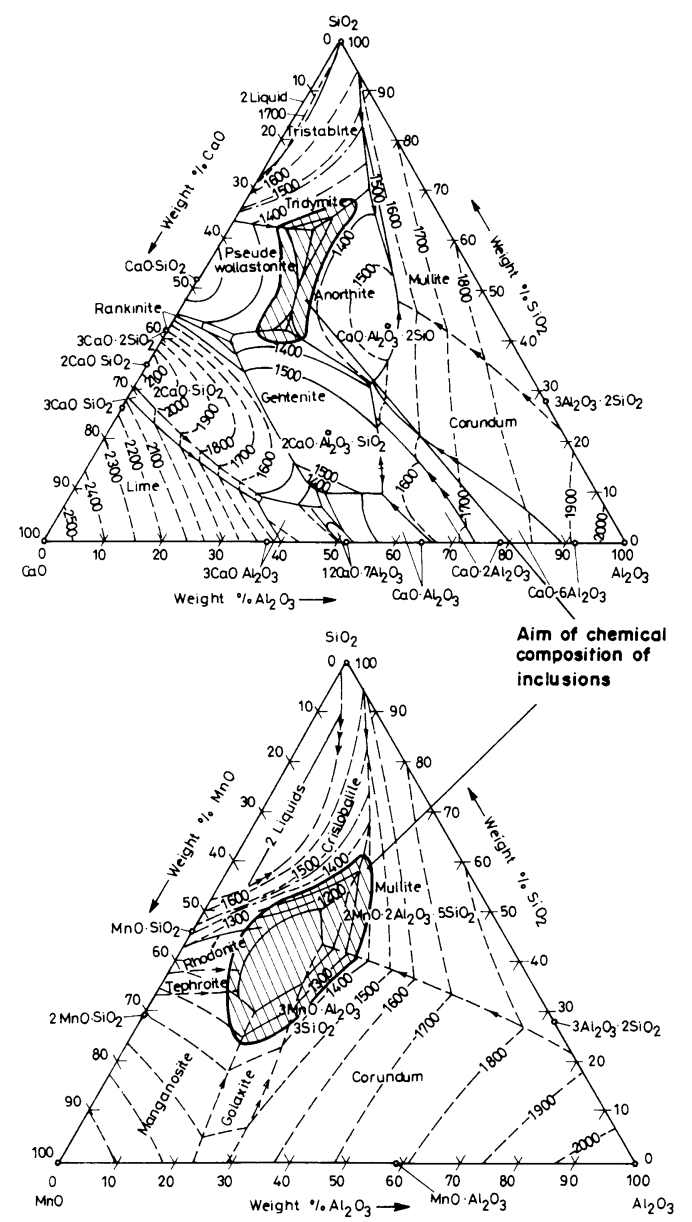

Fig. 15. Aim of chemical composition of inclusions.

$\mathrm{MnO}-\mathrm{SiO}_{2}-\mathrm{Al}_{2} \mathrm{O}_{3}$ 系の 2 種類に分類される ${ }^{11)}$. Fig. 15 に $\mathrm{CaO}-\mathrm{SlO}_{2}-\mathrm{Al}_{2} \mathrm{O}_{3}$ 系及び $\mathrm{MnO}-\mathrm{SiO}_{2}-\mathrm{Al}_{2} \mathrm{O}_{3}$ 系に扮け る介在物の延性領域を示す. $\mathrm{CaO}-\mathrm{SiO}_{2}-\mathrm{Al}_{2} \mathrm{O}_{3}$ 系では Wollastonite $と$ Anorthite $の$ 共晶線上, $\mathrm{MnO}$ $\mathrm{SiO}_{2}-\mathrm{Al}_{2} \mathrm{O}_{3}$ 系では Spessartite 初晶域の融点が最も低 い. 二つの系ともに, 適正介在物組成の $\mathrm{Al}_{2} \mathrm{O}_{3}$ 濃度は $20 \%$ 程度であり，この組成に介在物をコントロールす る必要がある。

介在物中 $\mathrm{Al}_{2} \mathrm{O}_{3}$ 濃度を目標の $20 \%$ にするためには, これに影響する要因と考えられる溶鋼中の $[\mathrm{Al}]$ ，及び 加熱精錬時のスラグ組成を抑制する必要がある. Fig. 16 に連鋳タンディッシュ内での Sol. Al 分析値と介在 物中 $\mathrm{Al}_{2} \mathrm{O}_{3}$ 濃度の関係を示す. Sol. $\mathrm{Al}$ が高いほど介在 物中の $\mathrm{Al}_{2} \mathrm{O}_{3}$ 濃度は増加し, Sol. $\mathrm{Al}$ を約 $4 \mathrm{ppm}$ にする

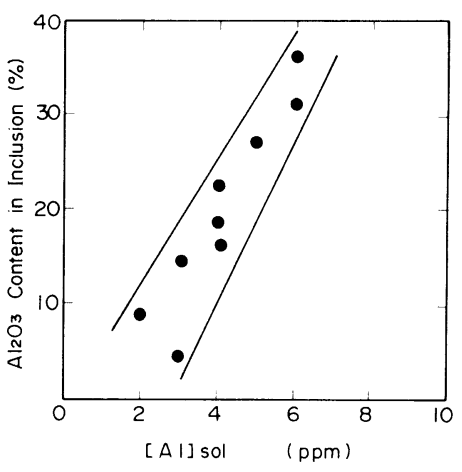

Fig. 16. Relation between $[\mathrm{Al}]_{\text {sol. }}$ and $\mathrm{Al}_{2} \mathrm{O}_{3}$ content in inclusion.

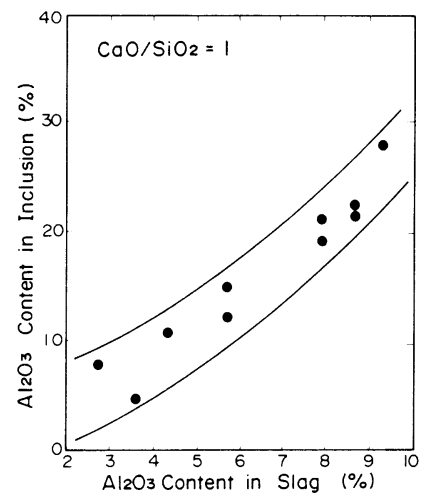

Fig. 17. Relation between $\mathrm{Al}_{2} \mathrm{O}_{3}$ content in slag and $\mathrm{Al}_{2} \mathrm{O}_{3}$ content in inclusion.

ことによつて介在物中の $\mathrm{Al}_{2} \mathrm{O}_{3}$ 濃度を目標の的 $20 \%$ に することができる.

いま，スラグーメタル間に平衡関係 ${ }^{12)}$ を仮定すると， $a_{\mathrm{Si}}$ は溶鋼目標組成により一定であり, 溶鋼中の $[\mathrm{Al}]$ はスラグ中の $a_{\mathrm{Al}_{2} \mathrm{O}_{3}}, a_{\mathrm{SiO}_{2}}$ により決まる.このことから， 介在物中の $\mathrm{Al}_{2} \mathrm{O}_{3}$ 濃度はスラグ中 $\mathrm{Al}_{2} \mathrm{O}_{3}$ 濃度と塩基度 によりコントロールすることが可能であると考えられ る.

$$
\begin{aligned}
& \underline{\mathrm{Si}}+2 \underline{\mathrm{O}}=\mathrm{SiO}_{2} \\
& \log \frac{a_{\mathrm{SiO}_{2}}}{a_{\mathrm{Si}} \cdot a_{0}{ }^{2}}=\frac{30110}{T}-11.40 \\
& 2 \underline{\mathrm{Al}}+3 \underline{\mathrm{O}}=\mathrm{Al}_{2} \mathrm{O}_{3} \\
& \log \frac{a_{\mathrm{Al}_{2} \mathrm{O}_{3}}}{a_{\mathrm{Al}}{ }^{2} \cdot a_{0}{ }^{3}}=\frac{64000}{T}-20.57
\end{aligned}
$$

Fig. 17 には実操業において, 上置きスラグの塩基度 $\left(\mathrm{CaO} / \mathrm{SiO}_{2}\right)$ を約 1 とした時の, スラグ中の $\mathrm{Al}_{2} \mathrm{O}_{3}$ 濃 度と $\mathrm{LF}$ 処理後における介在物中の $\mathrm{Al}_{2} \mathrm{O}_{3}$ 濃度との関 


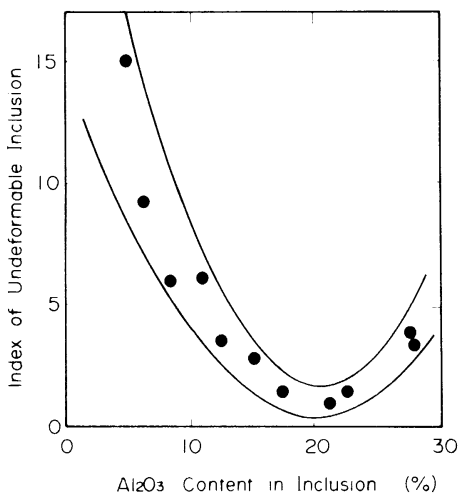

Fig. 18. Relation between $\mathrm{Al}_{2} \mathrm{O}_{3}$ content in inclusion and index of undeformable inclusion.

係を示す。 スラグ塩基度が約 1 では，スラグ中 $\mathrm{Al}_{2} \mathrm{O}_{3}$ 濃度を約 $8 \%$ にコントロールすることにより, 介在物 中 $\mathrm{Al}_{2} \mathrm{O}_{3}$ 濃度を適正なレベルに制御することが可能で ある. Fig. 18 には, 鋳片の介在物中 $\mathrm{Al}_{2} \mathrm{O}_{3}$ 濃度と線材 での非延性介在物指数との関係を示す。以上の方法によ り，介在物中 $\mathrm{Al}_{2} \mathrm{O}_{3}$ 濃度を約 $20 \%$ に制御した結果, 介 在物起因の断線は著しく減少した。

一方, 中心偏析の改善対策として, 溶鋼過熱度の低減 及び低りん化が効果的である．LF 法は RH 法と比較し て，溶鋼温度の調整が容易であり，また加熱精錬によつ て取鍋蓄熱量が増加するため鋳造中の温度降下が小さ く，過熱度を小さくして中心偏析を低隇するのに有利で ある。また，LF 工程では転炉の低温出鋼による吹止め [P] の低減，ならびにスラグドラッガーによる復りん 防止により，[P] $\leqq 0.005 \%$ の低りん夕イヤコード用鋼 の溶製も可能である.

以上のように, 要求品質の綮しいタイヤコード用鋼の 製造にLF 処理を適用し, 介在物の形態制御ならびに 中心偏析の改善をはかつた結果, 高品質のタイヤコード 用鋼の製造が叮能となつた。

\section{5. 結言}

高品質の鋼材を安定して，合理的に溶製することを目 的として，アーク加熱・スラグ精錬・除滓の機能を有し た取鍋加熱精錬設備を建設し，諸機能の改善をはかると
ともに漬浄鋼の製造技術を確立した.

(1) 上吹きガス攪找により，スラグーメタル間の物質 移動特性は, 誘導攪拌による ASEA-SKF 法及び底吹 き攪找による従来の LF 法と比べて著しく改善されて いる.この差は，スラグーメタル界面の乱流変動速度に より説明することができる.

（2）スラグ性状を低融点, 高流動性にすることにより, オープンアークを防止し, 溶鋼への伝熱を改善して, 高 い加熱速度が得られた。同時に，スラグ中の $\mathrm{MgO}$ 濃度 を調整することにより，取鍋耐火物の溶損を抑制するこ とが可能になつた。

( 3 ) $\mathrm{MgO}$ を添加した $\mathrm{CaO}-\mathrm{MgO}-\mathrm{SiO}_{2}-\mathrm{Al}_{2} \mathrm{O}_{3}$ 系高塩 基度スラグを用いることにより，耐火物の溶損を抑制し つつ, 高い脱硫率が得られ， $\mathrm{S} \leqq 10 \mathrm{ppm}$ の極低硫鋼を 安定して溶製することができた。また，Free limeを少 量存在させるように $\mathrm{MgO}$ を添加することにより, $\mathrm{MgO}$ 添加による $\mathrm{S}$ 分配比の低下はほとんど認められなかつ た.

（4）上置きスラグを用いたスラグ精錬により，タイヤ コード用鋼の介在物形態制御を行つた。その結果，介在 物中の $\mathrm{Al}_{2} \mathrm{O}_{3}$ 濃度を適正にコントロールすることによ り，断線回数の少ない高品質タイヤコード用鋼の製造が 可能になつた.

\section{文献}

1 ) 小川兼広, 伊東修三, 尾上俊雄, 牧野武久, 成田貴一: 鉄と鋼, 70 (1984), A 181

2 ) Y. SundBerg: Scand. J. Metall., 7 (1978), p. 81

3 ）森一美, 佐野正道: 鉄と鋼, 67 (1981), p. 672

4 ) 浅井滋生, 岡本徹夫, 赫冀成, 鞭厳: 鉄と鋼, 68 (1982), p. 426

5 ) E. F. Osborn, R. C. De VRies, K. H. GeE and H. M. Kraner: J. Metals. Trans., 6 (1954), p. 33

6 ) Verein Deutscher Eisenhüttenleute: Slag Atlas (1981), p. 193 [Verlag Stahleisen M. B. H.]

7 ) 小倉康嗣, 菊池良輝, 長谷川輝之, 松尾和彦, 田口喜代美, 半明正之: 鉄と鋼, 72 (1986), p. 1309

8 ) J. A. Duffy ang M. D. Ingram: J. Non-Cryst. Solids, 21 (1976), p. 373

9 ）水渡英昭，井上 亮: 鉄と鋼，70（1984），A157

10) D. J. Sosinsky and I. D. SommERville: Metall. Trans. B, 17 (1986), p. 331

11）斉藤 忠, 横江寛治, 嶋津真一, 柴田隆雄, 山田凱朗, 隠岐保博: 神戸製鋼技報 R \& D, 34 (1984), p. 96

12）学振第 19 委, 製鋼反応の推奖平衡値 (1984), p. 38 , p. 131 